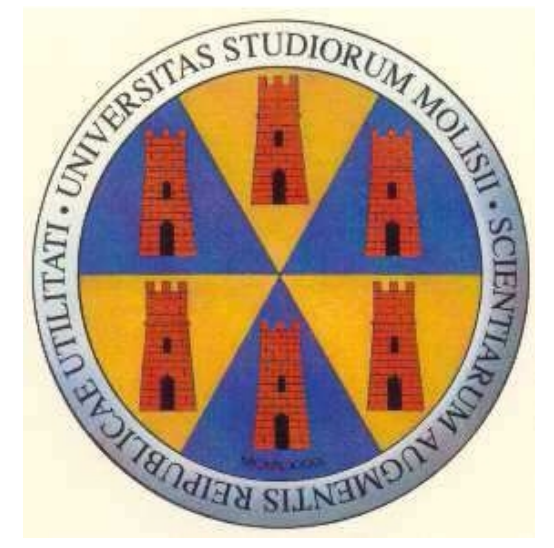

ECONOMICS \& STATISTICS DISCUSSION PAPER

No. 074/14

\title{
The determinants of abandoned M\&As in the banking sector
}

\author{
Stefano Caiazza
}

Alberto Franco Pozzolo 


\title{
The determinants of abandoned M\&As in the banking sector*
}

\author{
Stefano Caiazza \\ Università degli Studi di Roma "Tor Vergata" \\ Alberto Franco Pozzolo \\ Università degli Studi del Molise, CASMEF, MoFiR and Centro d'Agliano
}

\begin{abstract}
The consolidation process that characterized the banking industry in the last decades has been widely analyzed, but very few studies have investigated what are the reasons why a number of announced deals were not concluded. We fill this gap in the literature analyzing the characteristics of abandoned M\&A operations in a large sample that includes all the major domestic and cross-border deals in the banking sector announced worldwide between 1992 and 2010. The results show that hostile operations, deals of larger size and deals implying swaps of shares are less likely to be concluded. Controlling for size, cross-border operations are more likely to be successfully concluded, contrary to the expectation that the presence of strong cultural barriers and regulations, implicit and explicit, could determine a higher abandonment ratio. Finally, deals announced in countries with stronger supervisory authorities have a higher probability of failure.
\end{abstract}

JEL classification: G15, G21, G34

Keywords: M\&As, bank, abandoned deals

\footnotetext{
* The paper originates from the inter-university research project "Banking mergers and acquisitions bank in Europe in the '90s. Effects of ownership structure and regulation on profitability, efficiency and internationalization of European banking groups", coordinated by Michele Bagella, granted by the Ministry of Education (protocol number 2006134152). We would like to thank Paolo Bianco for helpful research assistance, and participants at the XXI International Conference on Money, Banking and Finance, Rome 10-11 December 2012, at 55 $5^{\text {th }}$ Congress of the Società Italiana degli Economisti, Bologna 24-26 October 2013 and at the IFABS $6^{\text {th }}$ International Conference, Lisbon 18-20 June 2014 for comments and suggestions. All remaining errors are of course our own responsibility.
} 


\section{Introduction}

Corporate transactions have a critical role in market economies. The competition for corporate control is one of the main tools through which inefficient administrators can be removed and unprofitable companies can be reconverted. In the banking sector, the large wave of mergers and acquisitions (M\&As) registered in the United States during the '80s (followed a little later in Europe, fostered by the II EU Directive on the Single Market) have increased significantly the efficiency of the credit allocation mechanism.

However, the financial crisis of 2007-2008 has made it clear that the financial sector was not following an equilibrium path, and the process of consolidation itself had contributed to the creation of banking conglomerates that were too big and too complex to save. This has caused a sharp reduction also in the number and value of M\&As in the banking sector, from 1,309 in 2007 to only 744 in 2010 . Moreover, many of the deals concluded in the most recent years were organized mainly avoid the failure of insolvent intermediaries.

The processes of consolidation in the banking sector has been studied extensively and there is now a broad consensus on the determinants of domestic and cross-border M\&As: larger and more profitable banks typically acquire weaker financial intermediaries, with the aim to restructure and increase efficiency (Focarelli et al., 2002). ${ }^{1}$ However, there is still a relevant piece of information that has not been analyzed carefully in the empirical literature: the determinants of the abandonment of deals that had been announced but are never finalized.

In general, the phenomenon of abandoned deals is not negligible. O'Sullivan and Wong (1998), for example, show that in the United Kingdom between 1989 and 1995 almost 20\% of the publicly announced transactions among all types of firms has not been concluded. Wong et al. (2001) argue that the failure may depend on several factors: the intervention of regulatory authorities; the success of defensive strategies implemented by the management of the target company; the emergence of conditions that determine a volunteer withdrawal by the acquired company.

However, although a number of studies has analyzed the determinants of abandoned M\&As in the case of non-financial companies, to the best of our knowledge, analyses of the banking industry are still lacking. ${ }^{2}$ This is even more surprising since the phenomenon is

\footnotetext{
${ }^{1}$ Reviews of the literature on bank mergers are provided by Amel et al. (2004) and DeYoung et al. (2009).

${ }^{2}$ An exception is the unpublished paper of Lorenz and Schiereck (2007) that we discuss in more detail below.
} 
quantitatively relevant also among banks: on average, about $5 \%$ of the deals announced in the world are not concluded, with peaks of over $10 \%$ in more financially advanced countries. Moreover, abandoned deals are among the most important: the average value of the transactions that are not successfully completed is more than twice that of the transactions successfully concluded. Indeed, a number of papers (e.g., Focarelli and Pozzolo, 2001; Pozzolo, 2009) have argued that the pervasive influence of information asymmetries (Morgan, 2002) and the stronger role of regulation authorities make the determinants and the pattern of M\&As in the banking sector not fully comparable with those of operations among non-financial industries. All these reasons call for a specific analysis for what the determinants of abandonment of M\&As in the banking sector are.

In this paper we try to fill this gap in the literature by studying the characteristics of abandoned M\&As in the banking sector. Our empirical analysis is based on more than 20,000 domestic and cross-border operations, announced in over 150 countries around the world between 1992 and 2010. The results show that friendly and cash-regulated operations have a greater probability of success. Moreover, contrary to the expectation that the presence of strong cultural differences, regulations, and other implicit and explicit barriers could determine a higher abandonment ratio in the case of international operations, cross-border deals are more likely to be successful than domestic deals. Operations of higher value, both in absolute term and relative to the size of the bidder, with more than one bidder, requiring longer negotiations and with targets incorporated in countries with stricter regulatory authorities and a more developed banking sector have instead a lower probability of success.

The rest of the paper is organized as follows. Section 2 sets the framework for the analysis, describing the results of the previous literature and the major hypotheses behind our empirical analysis. Section 3 describes the sources of the data and comments the major trends and Section 4 presents the econometric framework. The results of the econometric analysis are presented in Section 5. Section 6 concludes.

\section{The determinants of the abandonment of announced M\&As}

\section{a. Previous evidence}

The determinants and the effects of M\&As in the banking sector have been extensively analyzed in the theoretical and empirical literature. In a nutshell, the available evidence shows that larger 
and more profitable banks acquire weaker banks with the aim to restructure them and increase their efficiency (Focarelli et al., 2002), although acquirers typically register a drop in their stock prices at the moment of the announcement of the deal, especially in the case of diversifying and cross-border operations (DeLong, 2001).

However, not all announced deals end up being concluded, either because the parties involved do not find a satisfactory agreement, or because the target of the operation successfully adopts defensive techniques or finds an alternative acquirer. Understanding the reasons why some deals are abandoned is important, because it allows to better assess the likelihood of success of a planned operation, reducing the costs of an announcement to the market followed by a withdrawal. In fact, organizing an M\&A is very costly, because of the effort that it requires to internal managers and external advisors to plan and organize the operation from an economic, financial and legal viewpoint, that typically requires months of activity of large teams of highly skilled and highly remunerated professionals. From the point of view of the target, evaluating the offer, bargaining on the conditions of the deal, and eventually organizing a defense can also be very expensive. In addition, once an operation is announced, its abandonment typically implies a strong negative reaction of the stock price of the bidder (Lorenz and Schiereck, 2007), that can in turn make it the target of a possible acquisition, and normally leads to the removal of the management (Franks and Mayer, 1996 and Agrawal and Walking, 1996).

Despite its practical importance, the theoretical and empirical literature on the determinants of M\&A abandonments is rather limited. Based on these works, we can list at least five major characteristics that may affect the success of an M\&A.

First, a convincing evidence shows that the most critical feature is the reaction of management of the target company. Jensen (1988) defines as hostile acquisitions all attempts of acquiring a company in which the management of the acquirer and that of the target are competing with each other to gain control of the new entity. Hostile takeovers are a fundamental tool in the market for corporate control (Kini et al., 2004), since they introduce an important element of competition, favoring the removal of inefficient or opportunist managers and thus increasing the value of the company. Indeed, hostile takeovers were relatively common in the United States and in the United Kingdom during the '80s (although in the following decades they became drastically less popular), and have become more common also in continental Europe in recent years (Martynova and Renneboog, 2008). 
However, there are many ways to oppose an hostile takeover, both before the offer occurs (pre-bid defenses) and after it is made (post-bid defenses). In the first case, for example, a defense strategy can be put in place by organizing a block of shareholders that are in favor of the incumbent management and declare themselves unavailable to sell their stakes. In alternative, this group of shareholders can sustain the use of debt to perform buy-back operations. Post-bid defense techniques may take the form of lobbying activities with institutional shareholders, trade unions and consumer groups, that can exert their pressure on the shareholders to reject the tender. A well-known post-bid defense strategy is also the organization of a counter-bid by part of buyers that are in favor of the incumbent management (also known as white knights). Additional post-bid defense techniques include the approval of prohibitively expensive restructuring plans, that would make unprofitable the reorganization of the company following the merger. These may include the payment of extraordinary dividends or the announcements of unexpected extraordinary profits (Sudarsaman, 1995; Holl and Kyriazis, 1997; Schoenberg and Thornton, 2006). Clearly, the availability of many different defensive techniques makes hostile operations less likely to succeed than non-hostile deals (Morck et al., 1989). Holl and Kyriazias (1996), for example, estimate that the probability of success of a friendly takeover bid, that is shared with the management of the target company, is $96 \%$, while that of a hostile takeover is $61 \%, 35 \%$ lower. Studying mergers planned in the United Kingdom between 1989 and 1993, O’Sullivan and Wong (1998) find that in 47\% of cases self-defense techniques prevented the success of hostile takeovers.

While hostile takeovers are an important feature of the market for corporate control of non-financial corporations, in the banking sector the practice of hostile bids is far less common. A likely reason is that bank M\&As require a more or less explicit approval by part of the regulatory authorities, that often act behind the curtains favoring the growth of "national champions" (Caiazza et al., 2012) or the bail-out of banks close to bankruptcy. ${ }^{3}$ In our empirical analysis, we will therefore control not only if a takeover is explicitly defined as hostile, but also the degree of risk aversion of the bank regulatory authorities of the target's country.

Partly related to the previous aspect, is the concession by the target of lockup clauses. Such clauses put a cost on the abandonment of the operation, granting to the bidder a call option

\footnotetext{
${ }^{3}$ Interestingly, some European countries do not allow the use of defensive techniques in the case of deals involving a bank, requiring explicitly the bank's management to remain neutral. Belgium, Germany, Italy, Luxembourg and the Netherlands are among the countries that have not adopted the neutrality-rule (European Commission, 2007).
} 
on the common shares (stock lockup) or on certain assets (asset lockup) of the target that can be exercised in case the target merged with another buyer, or granting in alternative the right to receive a cash compensation if the operation is abandoned. As expected, Coates and Subramanian (2000) and Bates and Lemmon (2003) find that deals with lockup clauses are less likely to fail. Consistent with this evidence, Betton and Eckbo (2000) also show that the probability of success is higher in presence of a previous agreement between the merging companies. In our analysis we will therefore control also for the presence of lockup clauses.

A second important characteristic that affects the probability that an announced deal is successful is the presence of more than one bidder. By construction, the presence of multiple bidders implies that, even if the target is eventually acquired by one of them, all other bidders will be forced to abandon their plans. But it may also be the case that in presence of multiple bidders the probability that any offer is successful is lower than with just one offer, for example because multiple bids make it clearer what the value of their corporation is to the target's managers and equity holders. The available empirical evidence on this issue is ambiguous: Betton and Eckbo (2000), for example, show that the presence of multiple potential bidders reduces the probability of success; but Cotter and Zenner (1994) show that competing bids increase the likelihood of success, while Walkling (1985) and Holl and Kyriazis (1996) find no statistically significant effect. Although the overwhelming role of regulatory authorities makes multiple bids less likely in the banking sector than in the non-financial sector, in our analysis we will control also for this feature.

A third characteristics that has a crucial impact on the likelihood of success of an acquisition is the of payment. In fact, cash payments eliminate any uncertainty over the value of the exchange, which can instead be more uncertain if the payment is made by means of an exchange of the shares of the merging corporations. Ang and Cheng (2006) find evidence consistent with this hypothesis, showing that bidders are more likely to use shares as a method of payment when their stock price is overvalued with respect to what is predicted from its fundamentals. However, on the specific issue of abandonment, Asquith (1983) and Jennings and Mazzeo (1993) find that, in the U.S., announced equity-paid M\&As are not more likely to be abandoned, but only cause a stronger drop in the bidder stock price than that of the announcement of cash-paid deals. In the case of Europe, the evidence is less neat (Martynova and Renneboog, 2008; Georgen and Renneboo, 2004; Jandik and Makhija, 2005). In our 
empirical analysis, we will control for M\&As that were announced to be paid fully in cash or partly in cash and partly by an equity exchange.

A fourth element that can affect the outcome of the offer is the size of the target. On the one side, the management of larger companies is more likely to have the capabilities and the strength to implement defensive techniques, reducing the probability of success. But, on the other side, potential buyers are typically attracted by large deals, involving targets of larger size (Sudarsanam, 1995, and O'Sullivan and Wong, 1998 and 1999), and therefore tend to organize such bids more carefully, in order to maximize the probability of success. Indeed, the empirical evidence in Wong and O'Sullivan (2001) and Martynova and Renneboog (2008) suggests that the second effect prevails: M\&A bids of larger corporations have a higher probability of success. In our empirical analysis, we will also control for the size of the target relative to that of the bidder.

Finally, a fifth factor that is likely to affect the probability of success of an announced M\&A is the share of capital already owned by the bidder (the toehold effect). Acquirers that already own part of a corporation are more likely to know its functioning, to have good relationships with the management, and to tailor the deal in a way that is satisfactory for the target's equity holders. In fact, Jeon (2009) shows that the probability of success increases when the percentage of the bidder already owns $5 \%$ or more of the capital of the target company. ${ }^{4}$

Despite the large number of M\&As that took place in the banking sector in the last decades, to the best of our knowledge the only study on abandoned deals in this sector is that by Lorenz and Schiereck (2007). In their analysis of 97 operations among European banks between 1996 and 2002, they show that failures are more likely when the bidder is small, it offers a high acquiring price and the announcement causes a significant drop in its stock price. In the following, we will try to fill this gap in the literature presenting the results of an empirical analysis of the abandonment of announced M\&As in the banking sector, based on a sample of more than 20,000 cases.

\footnotetext{
${ }^{4}$ An additional crucial feature that is likely to impact on the likelihood of success of an M\&A is the price offered for the acquisition. Lorenz and Schiereck (2007), for example, focusing on the banking sector find that failures are more likely when the bidder offers a high acquiring price, while Betton and Eckbo (2000), find that the probability of success increases with the premium offered with respect to the market stock price. Unfortunately, information on the premium paid by the bidder is not available for most of our sample, which includes among the targets a large number of unlisted banks.
} 


\section{b. The empirical hypotheses}

Consistent with the literature discussed above, the most relevant variables in explaining the likelihood that an announced M\&A operation is withdrawn are the characteristics of each deal.

One of the strengths of our analysis is the availability of information on a large sample of deals from over 169 countries, that allow us, among other hypotheses, to verify also if the probability of success of domestic and cross-border deals is systematically different. In our baseline specification, we conjecture that the probability that an announced deal is eventually abandoned depends on whether: it is a hostile operation; multiple bidders are present; the operation is domestic or cross-border; the acquisition is paid in cash, through an exchange of shares, or in a mixed form; lockup clauses were agreed ex-ante or not. In addition, we control for the length of the negotiation process before the deal is concluded or it is withdrawn: our a priori is that deals that take too much time to be finalized are more likely to fail.

While in the baseline specification we control for country characteristics including two separate sets of dummies for bidder and target, in additional specifications we also use crosscountry variability to study the impact of country specific characteristics on the probability of success of announced deals. To this aim, we substitute target countries' dummies with a set of characteristics of the economy and of the banking and financial sectors. ${ }^{5}$ In particular, we control for: the country's GDP per capita; the degree of risk aversion of its banking regulatory authorities (obtained applying the methodology of Buch and Delong (2008) to the updated version of the dataset by Barth et al. (2004)); the size of the banking sector and of the stock market (as a percentage to GDP); the ratio of the size of the banking sector and of the stock market (a measure of whether the country's financial system centers on banks or on stock markets); the degree of concentration of the banking sector. All these characteristics provide an indirect measure of the hostility towards M\&As. We expect that an announced deal is more likely to fail when the country of incorporation of the target bank has a more concentrated and developed banking sector, in absolute terms and relative to the stock market, and banking regulators with a higher degree of risk aversion. In this countries, the degree of competition in the market for corporate control is likely to be lower, and explicit and implicit defensive techniques are more easily accessible. We also expect that the overall level of development of

\footnotetext{
${ }^{5}$ We do not include simultaneously bidder and target countries' characteristics because in the case of domestic deals they coincide, causing collinearity problems.
} 
the economy, measured for example by GDP per capita, might have an impact, since this is also associated with better corporate governance (Kauffman et al., 2005). ${ }^{6}$

Finally, for a smaller number of operations, we are also able to control for some characteristics of bidder and target banks. In particular, we control for the absolute size of the deal, its relative size with respect to the total assets of the bidder, and the absolute size of the bidder. Consistent with previous evidence, we expect larger banks to be more likely to succeed when they bid in relatively smaller operations. In addition, we also control for the value of liquid assets of the target relative to the value of the deal, with the expectation that more liquid targets are more likely to be bale to put in place defensive strategies and make the operation fail.

\section{Data and summary statistics}

The empirical analysis is conducted on a large sample of M\&A operations recorded by Security Data Corporation (SDC) in the "Platinum Worldwide Merger and Acquisition Database". For each deal, SDC reports a large set of information, on the banks involved (the name, identification codes such as SEDOL and ISIN, the countries of operation), and of the deal (the dates of announcement and conclusion, the value, characteristics such as the type of operation and the method of payment). Table 1 reports the definition of the variables used in the empirical analysis and their sources.

Our initial sample includes 21,521 deals announced between 1992 and 2010 and involving banks in 169 countries. Of these, 20,539 were completed and 982 were withdrawn (4.6\% of the total). The distribution of deals through time is not homogeneous (Figure 1). On average, $4.7 \%$ of the total number of announced operations have been withdrawn, but although the total number of M\&As is evenly spread over the two periods before and after 2000 (respectively $51 \%$ and $49 \%$ of the total), the share of withdrawn operations is higher in the first part of the period $(65 \%)$.

The number and the outcome of the deals is also different across countries (Table 1). The United States have the highest number of M\&As (9,673 operations, 443 of which were abandoned), accounting for a bit less than half of the entire sample. It is followed by UK $(1,278$ of which 26 abandoned), Japan (920 and 29) and Germany (696 and 24). Among the countries

\footnotetext{
${ }^{6}$ As mentioned below, direct measures of corporate governance turned out to be insignificant.
} 
with more than 100 operations, the ratio between the number of abandoned and concluded operations is highest in Indonesia (13.9\%), Norway (12.5\%), Philippines (10.7\%), Malaysia (8.1\%), China (6.7\%) and Poland (6.4\%). It is particularly low in Russia (1.1\%), Singapore (1.4\%), the UK (2.0\%), Brazil (2.2\%), Sweden (2.9\%) and Switzerland (3.0\%).

Table 2 reports some descriptive statistics of the characteristics of operations, distinguishing also between abandoned (Panels B) and concluded deals (Panels C). The average and median size of abandoned operations is larger than that of successful deals (370 million of US\$ vs. 160 million for the mean, and 46 million vs. 26 million for the median). Abandoned operations also show a higher ratio of the value of the transaction to the bidder's total assets ( 0.09 vs. 0.06 for the mean and 0.03 vs. 0.01 for the median). The average size of bidders in the case of abandoned operations is larger than in the case of successful deals $(60,907$ million of US\$ vs. 55,318), but the median is smaller (3,680 vs. 4,003). Finally, the average and median ratio of liquid assets of the target to the transaction value is higher in the case of positively concluded deals ( 4.26 vs. 3.77 for the mean and 0.91 vs.0.87 for the median).

Focusing on the characteristics of the countries where the target bank is incorporated, there is no clear relationship with the probability that an announced M\&A is abandoned. Comparing the subsamples of completed and uncompleted deals, Table 3 shows that the average and median credit to GDP ratio is slightly higher for the sample of competed deals (134.4 vs. 128.5 for the mean and 140.3 vs. 135.5 for the median), but also that the average stock market is relatively more developed in comparison with the banking sector (1.81 vs. 1.72); GDP per capita is smaller in the sample of abandoned deals (28,964 vs. 26,612 for the mean and 30,047 vs. 28,763 for the median), while regulators' risk aversion and concentration are quite similar.

The pairways correlation matrix, reported in Table 4, shows that the probability that a deal is abandoned is strongly correlated only with it being a hostile operation and with the presence of multiple bidders. In most of the other cases the sign is consistent with the hypotheses described above, but the correlation itself is very low.

These first evidences therefore provide only weak evidence on the characteristics of the deals that are more likely to be abandoned. However, this may be due to the fact that mean and median comparisons and bilateral correlations may hide more complex patterns among, possibly correlated, deal and bank characteristics. For this reason, in the following we report the results of a multivariate econometric analysis aimed at verifying the combined effect of different characteristics on the probability of abandonment and on the duration of the deal. 


\section{Econometric specifications}

To study the probability of abandonment of an announced M\&A, our baseline econometric specification is the following binomial model:

$\operatorname{Pr}\left(Y_{i j k s t}=k\right)=F\left(X_{i j k s t,} B B_{i j t}, C C_{s t}, C D_{j s}, T D_{t}\right), \quad k=0,1$

where $Y_{i j k s t}=1$ if a deal in which bank $i$ of country $j$ bids for bank $k$ in country $s$ in year $t$ is abandoned and $Y_{i j k s t}=0$ if the deal is completed; $X_{i j k s t}$ is a vector of characteristics of each deal; $B B_{i j t}$ are characteristics of bidder banks at time $t ; C C_{s t}$ is a vector of characteristics of the country of incorporation of the target bank at time $t ; C D_{j s}$ are country dummies; and $T D_{t}$ are time dummies. The model is estimated using a probit specification, with standard errors clustered at the level of the country of the target bank.

In addition to the binomial specification model, we also estimate a survival-time data model using the method of proportional hazards regression first proposed by Cox (1972):

$\lambda\left(t_{i j k s t}\right)=e^{-\beta^{\prime} M_{i j k s t}} \lambda_{0}\left(t_{i j k s t}\right)$

where $\lambda_{0}$ is the 'baseline' hazard, and $M_{i j k s t}$, the set of explanatory variables affecting the hazard rate, is the same included in the binomial specification (i.e,, $M_{i j k s t}$ is obtained by stacking horizontally $X_{i j k s t}, B B_{i j t}, C C_{s t}, C D_{j s}$ and $T D_{t}$ ).

\section{Empirical results}

\section{a. Binomial specification}

Panel A of Table 5 presents the results of the binomial model including among the explanatory variables the characteristics of each deal and controlling for country characteristics with the country dummies.

Consistent with the previous literature, the results show that hostile deals are less likely to be concluded, as shown by the positive coefficient, statistically significant at $1 \%$ level. The marginal effect of 0.37 implies that the probability of abandonment increases is 37 percentages points higher if the deal is hostile than if it is amicable, a strong effect if compared with the unconditional probability of abandonment, which is $4.7 \%$. 
The presence of more than one potential bidder also has a strong positive and highly statistically significant effect on the probability of abandonment, with a marginal effect of 0.39 . While this is partly a mechanical result, because only one of the multiple bidders can eventually acquire the target, in unreported regressions (available from the authors upon request) we have verified that including a single observation for each target, taking the value of one if none of the bidders eventually concluded the deal, this result is still confirmed. This suggests that multiple bidders contrast each other, making it easier for the target to avoid the acquisition.

Cross-border deals are significantly less likely to be abandoned, although the marginal effect is less than $1 \%$. Since there are few doubts that organizing a cross-border deal entails higher explicit and implicit costs (Focarelli and Pozzolo, 2005; Chakrabarti et al., 2009, Pozzolo, 2009; Caiazza et al., 2014), this results suggest that banks follow a risk averse strategy, and only start and announce those operations that have a high probability of success.

Transactions in which the payment is made in shares have a lower probability to be completed, as evidenced by the positive and highly statistically significant coefficient of the associated dummy variable. Although the marginal effect is in this case just 3\%, this evidence is consistent with the view that a higher degree of uncertainty related to the difference between the price of exchange and the future development of the market price reduces the appeal of the deal. Similarly, deals paid part in cash and part with equity exchanges are also more likely to be abandoned, although the coefficient is in this case statistically significant only at the $10 \%$ level, and the marginal effect is less than $1 \%$.

Transactions including some type of lockup clause have a significantly lower probability of abandonment, consistent with the fact that they impose a high cost on additional potential bidders, but the marginal effect is also in this case relatively low (2.8\%).

As the length of the negotiation increases, the likelihood that the deal is concluded tends to decrease. The marginal effect of 0.0001 implies that a within sample one standard deviation change in the number of days leads to a $1.5 \%$ change in the probability that the deal is abandoned.

Finally, dummies for the specialization of the target banks, unreported for brevity, show that deals where the target is a commercial bank or a bank holding company are relatively more likely to be abandoned than those where the target is a saving and loan institution or a mortgage bank. 
While these results are consistent with the previous literature on the determinants of abandonment of M\&As in the non-financial sector, and with the conventional wisdom, what is more striking is the low marginal effect of most of the deal characteristics, except for the cases of hostile deals and those with multiple bidders.

Panel B of Table 5 presents the results of a specification similar to that in Panel A, but in which the dummy variables for each target country have been replaced by the characteristics of the target's economy and of its banking and financial sector. Despite a large drop in the number of observations, this second specification confirms the results of the previous one, with the only exception of the coefficient for cross-border operations, which remains negative but becomes statistically insignificant (although its marginal effect is larger than that of the previous specification).

Consistent with our hypothesis that regulators can have a strong power in hindering M\&A deals, the results show that operations involving targets incorporated in countries where the regulatory authorities have a higher degree of risk aversion are more likely to be abandoned, although the marginal effect of a within-sample one standard deviation change is less than $1 \%$ (as for most of the country characteristics). Similarly, abandonments are more likely when the target is incorporated in a country where the banking sector is larger, both relative to GDP and with respect to the stock market, consistent with the view that acquisitions in more developed banking markets are overall more difficult. Finally, operations involving targets of richer countries, that generally have higher transparency and a stronger rule of law, are less likely to fail. $^{7}$

Table 6 presents the results of a number of specifications that include among the explanatory variables some additional characteristics of the deal and of the bidder and target banks, not considered in the specifications of Table 5. Unfortunately, these information are not available for the full sample of deals, leading in some cases to a significant reduction in the number of observations available for the estimation.

Panel A shows the results of a specification with dummy variables for bidder and target countries, similar to that of Panel A of Table 5, but including in addition the value of the transaction. Although the number of observations drops to 10,922 , slightly more than half of those initially available, the results are reassuring on the robustness of the previous estimates,

\footnotetext{
${ }^{7}$ However, in unreported regressions we have not been able to find that explicit measures of the rule of law have a statistically significant effect on the probability of abandonment.
} 
as shown by the broad invariance of the coefficients and the marginal effects with respect to those reported in Table 5. The only exception is the coefficient of the dummies for transactions settled through equity exchanges and with a mix of cash and equity exchanges, which become statistically insignificant. However, in unreported additional regressions we have verified that the loss of statistical significance is due to the reduction of the sample size, and not to the possible distortion induced by the lack of control for the size of the transaction in the previous regressions.

Interestingly, the coefficient of the logarithm of the transaction value is positive and statistically significant at $1 \%$ confidence level. In the banking sector, larger deals have therefore a lower probability of success, contrary to what happens in the manufacturing sector; the marginal effect of a one standard deviation of the logarithm of the deal value is $1.7 \%$, that is non negligible with respect to the sample unconditional mean of $4.8 \%$.

The results presented in Panel B, obtained from an even smaller sample of 4,535 observations, also confirm the importance of the relative size of the banks involved in the deal. ${ }^{8}$ Not only deals that are larger in absolute value have a lower probability of success, but also transactions in which the bidding bank is larger have a lower probability of being abandoned. The coefficient in this case is statistically significant at $1 \%$ level, although the marginal effect of a one standard deviation change is less than $1 \%$. The relative size of the deal with respect to the total assets of the bidding bank has instead no statistically significant effect.

Finally, in the specification reported in Panel $\mathrm{C}$ we have added as an additional explanatory variable the value of the liquid assets of the target bank as a ratio to the total value of the deal. The number of observations drops in this case to 882, making some of the coefficients previously estimated statistically insignificant. In particular, those of the lockup clause, of the length of the negotiation and, noticeably, of the value of the transaction. However, also in this case we have verified that the loss of statistical significance is due to the reduction of the sample size and not to the possible distortion induced by omitting to control for the level of liquid assets of the target bank. Consistent with our expectations, target banks with greater liquidity are more able to oppose to the acquisition, significantly increasing the probability that they are abandoned, although with a small marginal effect.

\footnotetext{
${ }^{8}$ Noticeably, in this and the following specifications of Panel C, the coefficient of the dummy for stock payments is again statistically significant.
} 


\section{b. Survival time model}

To gain a better understanding of the reasons why longer negotiations are more likely to lead to the abandonment of an operation, we have finally estimated the duration model described in equation (2). The results reported in Table 7 provide strong support to the view that deals that are more likely to be abandoned share the same characteristics as those that require longer negotiations. Indeed, longer negotiations typically regard hostile deals, deals with multiple bidders, deals paid by equity exchanges, and larger deals (Panel B). On the contrary, cross-border deals, those involving institutions with a lockup clause, and those where the bidder is a larger bank are more likely to succeed.

\section{Conclusions}

M\&As in the banking sector have helped in the past three decades to radically change financial markets, becoming a characterizing element of that process of international integration that is generically defined as "globalization”. Determinants, directions and consequences of bank M\&As have been analyzed in detail, but little is known of the reasons why some operations that are announced turn out to be unsuccessful.

This study sought to answer this question. The results of the empirical analysis are consistent with expectations and with economic rationality: the operations most likely to fail are those hostile and for which the final value of the payment is more uncertain, as in the case of equity swaps. More interestingly, our evidence shows that larger deals have a greater probability of failure, even though is it reasonable to expect that they are those better organized. Even controlling for size, cross-border operations are instead more likely to succeed, contrary to the expectation that the presence of strong cultural barriers and regulations could determine a higher abandonment ratio. Greater interference of supervisory authorities, not always fully favorable to a competitive market for corporate control, leads instead to a higher probability of failure. Finally, we have found that deals that are more likely to be abandoned are also more likely to require longer negotiations, independent on their outcome.

Overall, the evidence presented in this paper suggests that large and hostile deals, and those where the target is incorporated in countries more capable of putting in place obstructive techniques are more likely to be unsuccessful. This provides additional evidence that the market for corporate control in the banking sector may not be fully competitive. Whether this is 
consistent with value and welfare maximization is a question that goes beyond our analysis and requires further research. 


\section{References}

Amel D., Banes C., Panetta F. and Salleo C., 2004. Consolidation and efficiency in the financial sector: a review of the international evidence. Journal of Banking and Finance, 28, 2493-2519.

Ang J.S. and Cheng Y., 2006. Direct evidence of the market-driven acquisition theory. The Journal of Financial Services Research, 39, 199- 216.

Asquith P., 1983. Merger bids, uncertainty, and stockholder returns. Journal of Financial Economics, 11, 51-83.

Barth J.R., Caprio G.J. and Levine R., 2004. Bank regulation and supervision: what works best? Journal of Financial Intermediation, 13, 205-248.

Bates T.W. and Lemmon M.L., 2003. Breaking up is hard to do? An analysis of termination fee provisions and merger outcomes. Journal of Financial Economics, 69, 469-504.

Betton S. and Eckbo B.E., 2000. Toeholds, bid-jumps and expected payoffs in takeovers. The Review of Financial Studies, 13, 841-882.

Buch BC.M. and DeLong G., 2008. Do weak supervisory systems encourage bank risk-taking? Journal of Financial Stability,4, 23-29.

Caiazza S., Pozzolo A.F. and Trovato G., 2014. Do domestic and cross-border M\&As differ? Cross-country evidence from the banking sector. Journal of Financial Economics, 24, 967-981.

Caiazza S., Pozzolo A.F. and Claire A., 2012. What do bank acquires want? Evidence from worldwide bank M\&A targets. Journal of Banking and Finance, 36, 2641-2659.

Coates J.C. and Subramanian G., 2000. A buy side model of lockups: theory and evidence. Stanford Law Review, 53, 307-396.

Cotter J.F. and Zenner M., 1994. How managerial wealth affects the tender process. Journal of Financial Economics, 35, 63-97.

Cox, D., 1972. Regression Models and Life Tables, Journal of the Royal Statisical Society, Series B 34, 187-220.

DeLong G.L., 2001. Stockholder gains from focusing versus diversifying bank mergers. Journal of Financial Economics, 59, 221-252.

DeYoung R., Evanoff D.D. and Molyneux P., 2009. Mergers and acquisitions of the financial institutions: a review of the post-2000 literature. Journal of Financial Services Research, 2-3, 87-110.

European Commission, 2007. Report on the implementation of the directive of takeover bids. Commission Staff Working Document. 
Focarelli, D., Pozzolo, A. F. (2001). The patterns of cross-border bank mergers and shareholdings in OECD countries. Journal of banking \& Finance, 25, 2305-2337.

Focarelli D. and Pozzolo A.F., 2005. Where do banks expand abroad? An empirical analysis? Journal of Business, 78, 2435-2464.

Focarelli D., Panetta F. and Salleo, C., 2002. Why do banks merge? Journal of Money Credit and Banking, 34, 1047-66.

Franks, J. and Mayer, C., 1996. Hostile takeovers and the correction of managerial failure. Journal of Financial Economics 40, 163-181.

Goergen, M. and Renneboog L., 2004. Shareholder wealth effects of European domestic and cross-border takeover bids, European Financial Management, 10, 9-45.

Holl P. and Kyriazis D., 1997. Agency, bid resistance and the market for corporate control. Journal of Business Finance and Accounting, 24, 1037-1066.

Holl P. and Kyriazis D., 1996. The determinants of outcome in the UK take-over bids. International Journal of the Economics and Business, 3, 165-184.

Jandik T. and Makhija A.K., 2005. The impact of the structure of debt on target gains. SSRN n. 679026.

Jennings R.H. and Mazzeo M.A., 1993. Competing bids, target management resistance, and the structure of takeover bids. The Review of Financial Studies, 6, 883-909.

Jensen M.C., 1988. Takeovers: their causes and consequences. Journal of Economic Perspectives, 2, 21-48.

Jeon J. Q., 2009. How much is reasonable? The size of termination fees in mergers and acquisitions. Journal of Corporate Finance, 17, 959-981.

Kaufmann, D., Kraay, A., Mastruzzi, M., 2005. Governance matters IV: governance indicators for 1996-2004. World bank policy research working paper 3630.

Kini O., Kracaw W. and Mian, S., 2004. The nature of discipline by corporate takeovers. Journal of Finance, 59, 1511-1552.

Lorenz J.T. e Schiereck D., 2007. Completed versus cancelled banking M\&A transactions in Europe, Working paper.

Martynova M. and Renneboog L., 2008. A century of corporate takeovers: what have we learned and where do we stand. Journal of Banking and Finance, 32, 2148-2177.

Morck R.M., Shleifer A. and Vishny R.W., 1989. Alternative mechanisms for corporate control. American Economic Review, 89, 842-852. 
Morgan D., 2002. Rating banks: risk and uncertainty in an opaque industry. American Economic Review, 92, 874-888.

O'Sullivan N. and Wong P., 1998. Internal versus external control: an analysis of the board composition and ownership in UK takeovers. Journal of Management and Governance, 2, 17 35 .

O’Sullivan N. and Wong P., 1999. Board composition. Ownership structure and hostile takeovers: some UK evidence. Accounting and Business Research, 29, 139-155.

Pozzolo A.F., 2009. Bank cross-border mergers and acquisitions (causes, consequences and recent trends). In Alessandrini P., Fratianni M. and Zazzaro A. (eds), The changing geography of banking and finance. Spinger.

Schoenberg R. and Thornton D., 2006. The impact of bid defences in Hostile Acquisitions. European Management Journal, 24, 142-150.

Sudarsanam, P.S., 1995, The role of defensive strategies and ownership structure of target firms: evidence from UK hostile takeover bids. European Financial Management, 1, 223-240.

Walking R.A., 1985. Predicting tender offer success: a logistic analysis. Journal of Financial and Quantitative Analysis, 20, 461-478.

Wong P. and O'Sullivan N., 2001. The determinant and consequences of abandoned takeovers. Journal of Economic Surveys, 15, 145-186. 
Figure 1

\section{Completed and abandoned M\&As}

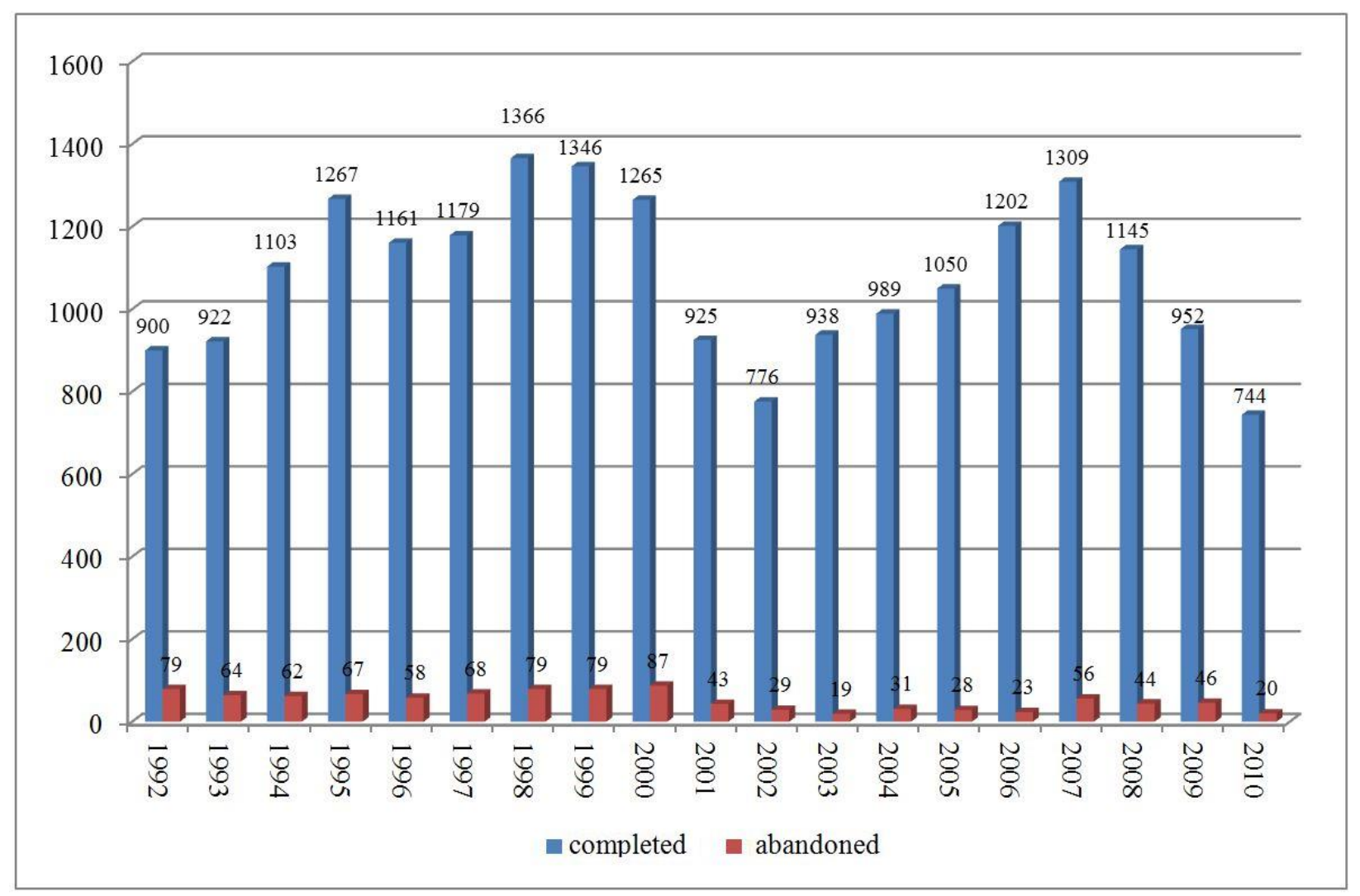

Completed and abandoned Mergers and Acquisitions between 1992 and 2010, recorded by Platinum Worldwide Mergers and Acquisition Database, provided by Security Data Corporation (SDC). 
Variable Description

\begin{tabular}{|c|c|c|}
\hline Variables & Source & Description \\
\hline \multicolumn{3}{|l|}{ Deal variables } \\
\hline Withdrawn & SDC & Dummy variable that takes the value 1 if the deal is withdrawn, 0 otherwise. \\
\hline Hostile & SDC & Dummy variable that takes the value 1 if the deal is hostile, 0 otherwise. \\
\hline Multi-bidders & SDC & Dummy variable that takes the value 1 if there are multiple bidders, 0 otherwise. \\
\hline Cross-border & SDC & $\begin{array}{l}\text { Dummy variable that takes the value } 1 \text { if the deal involves banks from different counties, } 0 \\
\text { otherwise. }\end{array}$ \\
\hline Stock payment & SDC & $\begin{array}{l}\text { Dummy variable that takes the value } 1 \text { if the payment of the transaction is settled with stocks, } 0 \\
\text { otherwise. }\end{array}$ \\
\hline Cash and stock & SDC & $\begin{array}{l}\text { Dummy variable that takes the value } 1 \text { if the payment of the transaction is settled in part with stocks } \\
\text { and in part with cash, } 0 \text { otherwise. }\end{array}$ \\
\hline Lockup & SDC & $\begin{array}{l}\text { Dummy variable that takes the value } 1 \text { if bidder has a call option on the common shares or on certain } \\
\text { assets of target bank, exercisable in the event of a merger with another buyer, } 0 \text { otherwise. }\end{array}$ \\
\hline Number of days & SDC & Number of days between the announcement data and the outcome data. \\
\hline Deal value & SDC & Log of the transaction value. \\
\hline Deal value / Tot ass. bidder & SDC & Ratio between the value of transaction and the total assets of bidder. \\
\hline Liquidity target / Deal value & SDC & Ratio of the liquid assets of the target over the value of the transaction. \\
\hline \multicolumn{3}{|l|}{ Country Variables } \\
\hline Credit to GDP & Word Bank & Total credit to GDP ratio. \\
\hline Stock market / GDP & Word Bank & Stock market capitalization to GDP ratio. \\
\hline Stock market / Credit & Word Bank & Stock market capitalization to total credit ratio. \\
\hline GDP per capita & $\mathrm{IMF}$ & GDP per capita. \\
\hline Concentration & Word Bank & Share of the total assets of a country's five largest banks over total bank asset. \\
\hline \multicolumn{3}{|l|}{ Regulatory Variable } \\
\hline Regulators risk aversion & $\begin{array}{c}\text { Buch and } \\
\text { DeLong (2008) }\end{array}$ & $\begin{array}{l}\text { Index that measures the sensitivity to the assumption of risk of the supervisory authorities and it } \\
\text { varies from } 0 \text { to } 12 \text { (higher value corresponds to a greater risk sensitivity). }\end{array}$ \\
\hline
\end{tabular}


Table 2

Deal and bank characteristics

\begin{tabular}{|c|c|c|c|c|c|c|}
\hline Variables & Obs. & Mean & Median & St. Dev. & Minimum & Maximum \\
\hline \multicolumn{7}{|c|}{ A. Full sample } \\
\hline Deal Value (USD millions) & 11,607 & 169.53 & 26.52 & 491.96 & 0.09 & 5.846 .10 \\
\hline Total asset bidder (USD billions) & 7,969 & $60,614.5$ & $3,687.40$ & $162,186.80$ & 5.90 & $1,266,359.00$ \\
\hline Deal Value / Tot asset bidder & 5,336 & 0.06 & 0.01 & 0.16 & 0.00 & 1.64 \\
\hline Liquidity target / Deal Value & 1,961 & 4.23 & 0.91 & 11.07 & 0.00 & 104.04 \\
\hline \multicolumn{7}{|c|}{ B. Completed deals } \\
\hline Deal Value (USD millions) & 11,080 & 160.00 & 25.91 & 464.91 & 0.09 & $5,846.10$ \\
\hline Total asset bidder (USD billions) & 7,552 & $60,906.97$ & $3,680.70$ & $162,752.90$ & 5.90 & $1,266,359.00$ \\
\hline Deal Value / Tot asset bidder & 5,101 & 0.06 & 0.01 & 0.16 & 0.00 & 1.64 \\
\hline Liquidity target / Deal Value & 1,850 & 4.26 & 0.91 & 11.23 & 0.00 & 104.04 \\
\hline \multicolumn{7}{|c|}{ C. Abandoned deals } \\
\hline Deal Value (USD millions) & 527 & 369.82 & 46.24 & 863.48 & 0.16 & $5,677.99$ \\
\hline Total asset bidder (USD billions) & 417 & $55,317.91$ & $4,003.70$ & $151,655.90$ & 6.40 & $1,207,825.00$ \\
\hline Deal Value / Tot asset bidder & 235 & 0.09 & 0.03 & 0.16 & 0.00 & 1.49 \\
\hline Liquidity target / Deal Value & 111 & 3.77 & 0.87 & 7.82 & 0.00 & 58.79 \\
\hline
\end{tabular}

Panel A presents the descriptive statistics for the entire sample, dropping observations with a value greater than the 99th percentile and below the first percentile of the sampling distribution; Panel B those for banks involved in an M\&A announced in the following year and eventually completed; Panel $\mathrm{C}$ for banks in an M\&A announced in the following year and eventually abandoned. 
Table 3

Country and regulatory characteristics

\begin{tabular}{|c|c|c|c|c|c|c|}
\hline \multicolumn{7}{|c|}{ A. Full sample } \\
\hline Variables & Obs. & Mean & Median & St. Dev. & Minimum & Maximum \\
\hline Credit / GDP target & 20,870 & 134.15 & 139.22 & 51.98 & 12.47 & 214.39 \\
\hline Stock market / GDP target & 20,683 & 97.91 & 99.34 & 45.75 & 4.77 & 265.29 \\
\hline Stock market / Credit target & 20,820 & 1.80 & 1.44 & 8.11 & 0.13 & 962.47 \\
\hline GDP per capita target & 21,122 & $28,856.79$ & $30,047.22$ & $11,886.64$ & $1,538.55$ & $50,008.19$ \\
\hline Concentration target & 15,046 & 59.26 & 56.21 & 22.60 & 28.54 & 100.00 \\
\hline Regulators risk aversion target & 21,049 & 8.28 & 10.00 & 2.23 & 2.00 & 11.00 \\
\hline \multicolumn{7}{|c|}{ B. Completed deals } \\
\hline Variables & Obs. & Mean & Median & St. Dev. & Minimum & Maximum \\
\hline Credit / GDP target & 19,920 & 134.42 & 140.28 & 51.90 & 12.47 & 214.39 \\
\hline Stock market / GDP target & 19,745 & 98.20 & 99.34 & 45.66 & 4.77 & 265.29 \\
\hline Stock market / Credit target & 19,870 & 1.81 & 1.44 & 8.301 & 0.13 & 962.47 \\
\hline GDP per capita target & 20,147 & $28,964.33$ & $30,047.22$ & $11,849.65$ & $1,538.55$ & $50,008.19$ \\
\hline Concentration target & 14,446 & 59.29 & 56.14 & 22.57 & 28.54 & 100.00 \\
\hline Regulators risk aversion target & 20,098 & 8.27 & 10.00 & 2.23 & 2.00 & 11.00 \\
\hline \multicolumn{7}{|c|}{ C. Abandoned deals } \\
\hline Variables & Obs. & Mean & Median & St. Dev. & Minimum & Maximum \\
\hline Credit / GDP target & 950 & 128.54 & 135.51 & 53.43 & 13.18 & 214.39 \\
\hline Stock market / GDP target & 938 & 91.73 & 86.42 & 47.30 & 5.04 & 265.29 \\
\hline Stock market / Credit target & 950 & 1.72 & 1.46 & 1.03 & 0.18 & 8.01 \\
\hline GDP per capita target & 965 & $26,611.60$ & $28,762.68$ & $12,429.80$ & $1,560.68$ & $49,797.25$ \\
\hline Concentration target & 600 & 58.54 & 57.21 & 23.38 & 28.54 & 100.00 \\
\hline Regulators risk aversion target & 951 & 8.42 & 10.00 & 2.20 & 2.00 & 11.00 \\
\hline
\end{tabular}

Panel A presents the descriptive statistics for the entire sample, dropping observations with a value greater than the 99th percentile and below the first percentile of the sampling distribution; Panel B those for banks involved in an M\&A announced in the following year and eventually completed; Panel $\mathrm{C}$ for banks in an M\&A announced in the following year and eventually abandoned. 


\section{Correlation matrix}

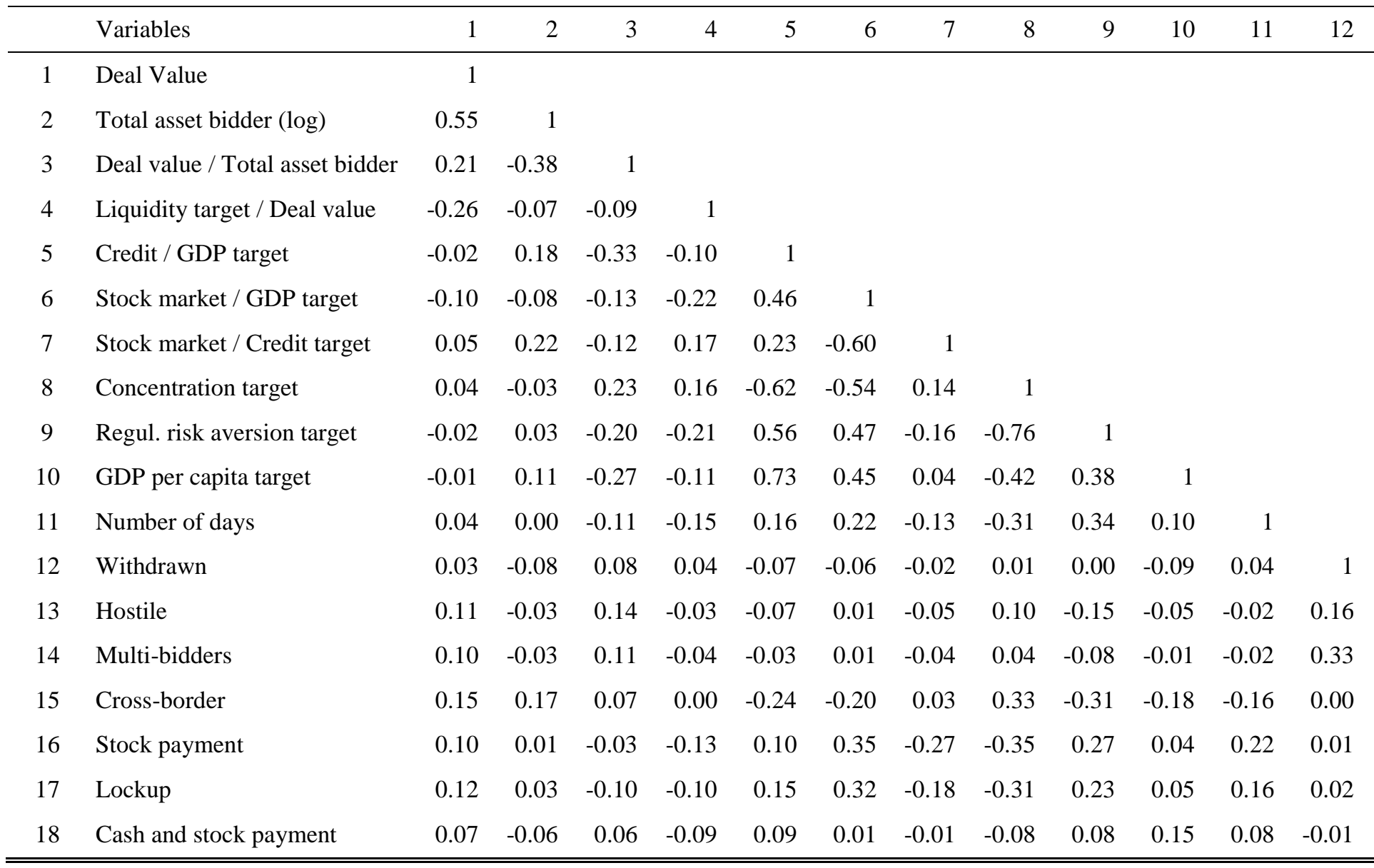


Deal characteristics, regulatory and country variables

\begin{tabular}{|c|c|c|c|c|}
\hline & \multicolumn{2}{|c|}{ Panel A } & \multicolumn{2}{|c|}{ Panel B } \\
\hline & Coefficient & Marginal Effect & Coefficient & Marginal Effect \\
\hline Hostile & $\begin{array}{r}1.48936 * * * \\
(0.4112)\end{array}$ & 0.3669 & $\begin{array}{r}1.3979 * * * \\
(0.4738)\end{array}$ & 0.3043 \\
\hline Multi-bidders & $\begin{array}{r}1.6372 * * * \\
(0.0652)\end{array}$ & 0.3907 & $\begin{array}{r}1.5951 * * * \\
(0.0985)\end{array}$ & 0.3717 \\
\hline Cross-border & $\begin{array}{r}-0.1461 * * * \\
(0.0592)\end{array}$ & -0.0020 & $\begin{array}{l}-0.0781 \\
(0.0655)\end{array}$ & -0.0046 \\
\hline Stocks payment & $\begin{array}{r}0.2261 * * * \\
(0.0611)\end{array}$ & 0.0322 & $\begin{array}{r}0.2116 * * * \\
(0.1034)\end{array}$ & 0.0317 \\
\hline Cash and stocks payment & $\begin{array}{l}0.1081^{*} \\
(0.0606)\end{array}$ & 0.0029 & $\begin{array}{r}0.1194 * * * \\
(0.0431)\end{array}$ & 0.0101 \\
\hline Lockup & $\begin{array}{r}-0.5712 * * * \\
(0.0633)\end{array}$ & -0.0281 & $\begin{array}{r}-0.5514 * * * \\
(0.1132)\end{array}$ & -0.0205 \\
\hline Number of days & $\begin{array}{r}0.0010^{* * * *} \\
(0.0001)\end{array}$ & 0.0001 & $\begin{array}{r}0.0011 * * * \\
(0.0002)\end{array}$ & 0.0001 \\
\hline $\begin{array}{l}\text { Regulators risk aversion } \\
\text { target }\end{array}$ & & & $\begin{array}{r}0.0423 * * * \\
(0.0163)\end{array}$ & 0.0038 \\
\hline $\begin{array}{l}\text { GDP per capita } \\
\text { target }\end{array}$ & & & $\begin{array}{r}-0.1509 * * * \\
(0.0454)\end{array}$ & -0.0076 \\
\hline $\begin{array}{l}\text { Credit to GDP } \\
\text { target }\end{array}$ & & & $\begin{array}{r}0.0045 * * * \\
(0.0016)\end{array}$ & 0.0001 \\
\hline $\begin{array}{l}\text { Stock market to GDP } \\
\text { target }\end{array}$ & & & $\begin{array}{r}-0.0039 * * * \\
(0.0012)\end{array}$ & -0.0002 \\
\hline $\begin{array}{l}\text { Stock market to credit } \\
\text { target }\end{array}$ & & & $\begin{array}{r}-0.1552 * * * \\
(0.0604)\end{array}$ & -0.0046 \\
\hline $\begin{array}{l}\text { Concentration } \\
\text { target }\end{array}$ & & & $\begin{array}{r}-0.0005 \\
(0.0027)\end{array}$ & -0.0002 \\
\hline Observations & 20,558 & & 13,970 & \\
\hline
\end{tabular}

The dependent variable takes the value of one if the deal was abandoned and zero if it was successful. For variable definitions, see Table 1. The model is estimated using a probit specification. In Panel A, dummies for specialization, bidder and target countries and years are included but not reported. In Panel B the specification does not include target country dummies. Standard errors are clustered at the country level. The symbol *** indicates a level of significance equal to 1 per cent or less; ** between 1 and 5 per cent; * between 5 and 10 percent. The marginal effects show the partial change in the likelihood with respect to the variation of each independent variable, evaluated at the sample mean value of each variable. 
Table 6

Deal characteristics individual variables

\begin{tabular}{|c|c|c|c|c|c|c|}
\hline & \multicolumn{2}{|c|}{ Panel A } & \multicolumn{2}{|c|}{ Panel B } & \multicolumn{2}{|c|}{ Panel C } \\
\hline & Coefficient & $\begin{array}{c}\text { Marginal } \\
\text { Effect }\end{array}$ & Coefficient & $\begin{array}{c}\text { Marginal } \\
\text { Effect }\end{array}$ & Coefficient & $\begin{array}{c}\text { Marginal } \\
\text { Effect }\end{array}$ \\
\hline Hostile & $\begin{array}{r}1.6179 * * * \\
(0.4376)\end{array}$ & 0.3657 & $\begin{array}{r}1.6989 * * * \\
(0.5550)\end{array}$ & 0.3640 & $\begin{array}{r}3.1975 * * \\
(1.4239)\end{array}$ & 0.3084 \\
\hline Multi-bidders & $\begin{array}{r}1.5404 * * * \\
(0.0693)\end{array}$ & 0.3135 & $\begin{array}{r}1.5727 * * * \\
(0.1674)\end{array}$ & 0.3237 & $\begin{array}{r}2.1038^{* * * *} \\
(0.0483)\end{array}$ & 0.3804 \\
\hline Cross-border & $\begin{array}{r}-0.4302^{* * * *} \\
(0.1028)\end{array}$ & -.0136 & $\begin{array}{r}-1.1761 * * * \\
(0.4061)\end{array}$ & 0.0016 & $\begin{array}{r}-8.7743 * * * \\
(0.5496)\end{array}$ & 0.0253 \\
\hline Stocks payment & $\begin{array}{r}0.0738 \\
(0.0866)\end{array}$ & 0.0184 & $\begin{array}{r}0.3235^{* * *} \\
(0.0839)\end{array}$ & 0.0342 & $\begin{array}{r}0.4911 * * * \\
(0.1701)\end{array}$ & 0.0203 \\
\hline $\begin{array}{l}\text { Cash and stocks } \\
\text { payment }\end{array}$ & $\begin{array}{r}-0.0523 \\
(0.0853)\end{array}$ & -0.0018 & $\begin{array}{r}0.0234 \\
(0.0451)\end{array}$ & 0.0031 & $\begin{array}{r}-0.1960 * * \\
(0.0963)\end{array}$ & -0.0112 \\
\hline Lockup & $\begin{array}{r}-0.5991 * * * \\
(0.0633)\end{array}$ & -0.0268 & $\begin{array}{r}-0.6271 * * * \\
(0.1213)\end{array}$ & -0.0262 & $\begin{array}{l}-0.0915 \\
(0.0685)\end{array}$ & -0.0157 \\
\hline Number of days & $\begin{array}{r}0.0011 * * * \\
(0.0001)\end{array}$ & 0.0001 & $\begin{array}{r}0.0008 * * * \\
(0.0002)\end{array}$ & 0.0001 & $\begin{array}{r}-0.0006 \\
(0.0004)\end{array}$ & 0.0000 \\
\hline Deal value $(\log )$ & $\begin{array}{r}0.0850 * * * \\
(0.0092)\end{array}$ & 0.0048 & $\begin{array}{r}0.1390 * * * \\
(0.0469)\end{array}$ & 0.0085 & $\begin{array}{r}0.0799 \\
(0.0645)\end{array}$ & 0.0130 \\
\hline $\begin{array}{l}\text { Deal value / } \\
\text { Total assets bidder }\end{array}$ & & & $\begin{array}{r}0.1324 \\
(0.21624)\end{array}$ & -0.0159 & $\begin{array}{l}0.6743 * \\
(0.3955)\end{array}$ & -0.0269 \\
\hline $\begin{array}{l}\text { Total assets bidder } \\
(\log )\end{array}$ & & & $\begin{array}{r}-0.11295 * * * \\
(0.0167)\end{array}$ & -0.0065 & $\begin{array}{r}-0.1399 * * * \\
(0.0430)\end{array}$ & -0.0104 \\
\hline $\begin{array}{l}\text { Liquidity target / Deal } \\
\text { value }\end{array}$ & & & & & $\begin{array}{r}0.0142 * * * \\
(0.0018)\end{array}$ & 0.0014 \\
\hline Observations & 10,870 & & 4,509 & & 882 & \\
\hline
\end{tabular}

The dependent variable takes the value of one if the deal was abandoned and zero if it was successful. For variable definitions, see Table 1. The model is estimated using a probit specification. In Panel A, dummies for specialization, bidder and target countries and years are included but not reported. In Panel B the specification does not include target country dummies. Standard errors are clustered at the country level. The symbol *** indicates a level of significance equal to 1 per cent or less; ** between 1 and 5 per cent; * between 5 and 10 percent. The marginal effects show the partial change in the likelihood with respect to the variation of each independent variable, evaluated at the sample mean value of each variable. 
Table 7

Survival Analysis

\begin{tabular}{|c|c|c|c|c|}
\hline & Panel A & Panel B & Panel C & Panel D \\
\hline & Coefficient & Coefficient & Coefficient & Coefficient \\
\hline Hostile & $\begin{array}{r}1.2403 * * * \\
(0.4393)\end{array}$ & $\begin{array}{r}1.4430 * * * \\
(0.4517)\end{array}$ & $\begin{array}{r}1.5159 * * \\
(0.6752)\end{array}$ & $\begin{array}{l}1.2709^{*} \\
(0.6515)\end{array}$ \\
\hline Multi-bidders & $\begin{array}{r}1.8696 * * * \\
(0.1004)\end{array}$ & $\begin{array}{r}1.9198 * * * \\
(0.1734)\end{array}$ & $\begin{array}{r}2.1722 * * * \\
(0.1521)\end{array}$ & $\begin{array}{r}2.1311 * * * \\
(0.1770)\end{array}$ \\
\hline Cross-border & $\begin{array}{r}-0.4394 * \\
(0.1715)\end{array}$ & $\begin{array}{r}-0.8059 * * * \\
(0.2671)\end{array}$ & $\begin{array}{r}-2.3008 * * \\
(1.1307)\end{array}$ & \\
\hline Stocks payment & $\begin{array}{r}0.1231 * * \\
(0.0596)\end{array}$ & $\begin{array}{r}0.1091 \\
(0.2671)\end{array}$ & $\begin{array}{r}0.3150 * * \\
(0.1318)\end{array}$ & $\begin{array}{r}0.0776 \\
(0.0971)\end{array}$ \\
\hline Cash and stocks payment & $\begin{array}{r}-0.0625 \\
(0.0747)\end{array}$ & $\begin{array}{r}-0.0741 \\
(0.0783)\end{array}$ & $\begin{array}{r}-0.1542 \\
(0.1125)\end{array}$ & $\begin{array}{r}0.0750 \\
(0.0875)\end{array}$ \\
\hline Lockup & $\begin{array}{r}-0.9756 * * * \\
(0.0770)\end{array}$ & $\begin{array}{r}-0.9727 * * * \\
(0.0664)\end{array}$ & $\begin{array}{r}-1.0237 * * * \\
(0.1644)\end{array}$ & \\
\hline Deal value (log) & & $\begin{array}{r}0.0797 * * * \\
(0.0210)\end{array}$ & $\begin{array}{r}0.2476 * * * \\
(0.0928)\end{array}$ & \\
\hline $\begin{array}{l}\text { Deal value / } \\
\text { Total assets bidder }\end{array}$ & & & $\begin{array}{r}0.0719 \\
(0.6276)\end{array}$ & \\
\hline Total assets bidder & & & $\begin{array}{r}-0.2388 * * * \\
(0.0435)\end{array}$ & \\
\hline $\begin{array}{l}\text { GDP per capita } \\
\text { target }\end{array}$ & & & & $\begin{array}{r}-0.0000^{*} \\
(0.000)\end{array}$ \\
\hline $\begin{array}{l}\text { Credit to GDP } \\
\text { target }\end{array}$ & & & & $\begin{array}{r}0.0083^{*} \\
(0.0043)\end{array}$ \\
\hline $\begin{array}{l}\text { Stock market to GDP } \\
\text { Target }\end{array}$ & & & & $\begin{array}{r}-0.0090 * * * \\
(0.0039)\end{array}$ \\
\hline $\begin{array}{l}\text { Stock market to credit } \\
\text { target }\end{array}$ & & & & $\begin{array}{l}-0.2500^{*} \\
(0.1462)\end{array}$ \\
\hline $\begin{array}{l}\text { Concentration } \\
\text { target }\end{array}$ & & & & $\begin{array}{r}0.0032 \\
(0.0075)\end{array}$ \\
\hline $\begin{array}{l}\text { Regulators risk aversion } \\
\text { target }\end{array}$ & & & & $\begin{array}{r}0.0451 \\
(0.0786)\end{array}$ \\
\hline Observations & 12,111 & 8,023 & 4,231 & 7,492 \\
\hline
\end{tabular}

The dependent variable is time elapsed between the deal announcement and outcome, considering the number of completed and abandoned deals. The model is estimated using the Cox specification. In Panel A, B and C dummies for specialization, target and bidder country are included. In Panel D the specification does not include target country dummies. Standard errors are clustered at the country level. The symbol $* * *$ indicates a level of significance equal to 1 per cent or less; ** between 1 and 5 per cent; * between 5 and 10 percent. 